\title{
Strategy of Increasing of Local Tax Revenues in Bandung City
}

\author{
Suryanto \\ Department of Business Administration \\ Universitas Padjadjaran \\ Bandung, Indonesia \\ email: suryanto@unpad.ac.id \\ Bambang Hermanto \\ Department of Business Administration \\ Universitas Padjadjaran \\ Bandung, Indonesia \\ email: b.hermanto@unpad.ac.id
}

\author{
Poni Sukaesih Kurniati \\ Government Studies Program \\ Universitas Komputer Indonesia \\ Bandung, Indonesia \\ email: poni.sukaesih@email.unikom.ac.id \\ Mas Rasmini \\ Department of Business Administration \\ Universitas Padjadjaran \\ Bandung, Indonesia \\ email: rasminimas@gmail.com
}

\begin{abstract}
The purpose of this research is to analyze the strategy of increasing local tax revenues in the city of Bandung. This research uses a qualitative approach to descriptive analysis approach. Primary data sources were obtained through in-depth interviews, field-direct observation and focus group discussions. The secondary data source obtained and collected from the compilation and data processing in the form of research results, scientific articles, publications, and documents related to the object of this study. The results showed that in order to increase local tax revenue in Bandung, several strategies have been implemented, among others: (1) Completion of local tax regulations; (2) Optimization of local tax collection; (3) Determination of target plan of regional tax revenue; (4) Establish a tax incentive/disincentive policy; (5) Building a Tax Service System; (6) Increasing public awareness and taxpayers; and (7) Establish a tax oversight system.
\end{abstract}

Keywords: Strategy; Acceptance; Regional Tax; Bandung City

\section{INTRODUCTION}

Regional autonomy and fiscal decentralization demand good regional financial management. Regional financial management includes efforts to optimize local revenue and efficiency of regional expenditure. One potential source of regional revenue under Law No.33 of 2004 on Financial Equilibrium between Central Government and Regional Government is Local Own Revenue (PAD). Sources of PAD consist of local taxes, user charges, other separated wealth management results, and other legitimate sources.

The main aspect of local revenue management that needs attention is PAD through local taxes. Local taxes according to Suryanto and Mas Rasmini (2017) taxes levied by local governments both provincial and district/city governments. The government is expected to increase PAD to reduce dependence on central financing, thereby increasing local discretion. An important step that must be taken by local governments to increase local revenue is to calculate the real potential of PAD owned by the regions, one of which according to Lutfi (2006) is through efforts to increase the fiscal capacity of regions which basically is the optimization of local revenue sources.

The issuance of Law Number 28 of 2009 on Regional Tax and Local Retribution is based on the lack of support for regulating the existing tax and levy authority in the implementation of Regional Autonomy. Providing greater authority to regions in the administration and service to the public should be followed by the granting of great authority also in taxation and retribution. A very limited base of the district and municipal taxes and the absence of provincial authority in determining tax rates have resulted in regions always experiencing difficulties meeting their expenditure needs. The enormous dependence of regions on balancing funds from the center is in many ways less reflective of regional accountability. Local governments are not encouraged to efficiently allocate budgets and local people do not want to control local budgets because they feel they are not burdened with taxes and user charges.

As part of the continuous improvement, the new Law improves 3 (three) main points, namely: (1) Completion of local tax collection and retribution system; (2) Providing greater authority to the regions in the field of taxation (local taxing empowerment), and (3) Improving the effectiveness of supervision. These three things run simultaneously so that efforts to increase the PAD is done in the corridor that has been determined and will be sanctioned in case of violation.

Completion of local tax collection and retribution system is done by changing the open list system to closed-list, (Siahaan, 2005). Regions may only collect the types of local taxes and regional levies listed in Law No. 28 of 2009 on Regional Taxes and Levies.

The use of local taxing power is done in various ways, among others: (1) increasing the types of local taxes and charges; (2) expanding existing regional taxes and levies; (3) 
transferring some types of central taxes into local taxes, and; (4) provide discretion to the regions to set tariffs.

The city of Bandung as one of the cities that has the potential of PAD from local taxes has a high commitment to maximizing PAD from local taxes. This can be seen from the target set from the local tax increases each year.

Table 1. Target Local Tax Bandung

\begin{tabular}{|c|c|}
\hline Year & Target (Rp) \\
\hline 2012 & 727.000 .000 .000 \\
\hline 2013 & 1.063 .000 .000 .000 \\
\hline 2014 & 1.400 .000 .000 .000 \\
\hline 2015 & 1.598 .000 .000 .000 \\
\hline 2016 & 1.850 .000 .000 .000 \\
\hline
\end{tabular}

Although the targeted tax increases every year, in fact, terget is still far from the potential tax that exists. The results of the study from LPPM Unpad (2015) mentioned that the potential of Bandung City tax from 9 (nine) types of local taxes each year can reach more than 2 trillion. The amount of potential tax that has not been explored shows still not optimal the way of tax collection in the city of Bandung. If it continues, then there will be the potential loss of local taxes that will affect the decrease in PAD Bandung.

In addition to the phenomenon of potential loss of local taxes, other problems that occur is the problem of taxpayers arrears are increasing each year. The taxpayers occurred in addition to the lack of awareness of taxpayers also because the tax administration system that is still not effective. Many tax collection systems are still using the manual system when technological progress has been very rapid. Efforts of local governments should continue to be improved in developing local tax administration so that efforts in increasing local tax revenue can be done well.

Efforts to optimize tax revenues require an effective administrative system that can also be used in carrying out governance both at local and central government levels. According to Carlos A. Silvani (2007) states that tax administration is said to be effective when able to overcome the problems of unregistered taxpayers, taxpayers who do not submit the Notice (SPT), tax smuggling, and tax arrears.

\section{RESEARCH METHODS}

The method used in this research is qualitative research method with descriptive approach. The main source of information that will be the reference data and research information consists of primary and secondary sources. Primary sources were obtained from in-depth interviews, focused discussions, and direct field observations. The secondary data source obtained and collected from the compilation and data processing in the form of research results, scientific articles, publications, and documents related to the object of this study. There will be no restriction of informants in this study, it's just that the information gathering process will stop after all the questions that have been a problem in the research have been answered. The research will start from key informants that will continue to other informants. The stage of information extraction consists of the Head of Regional Revenue Management
Agency (BPPD) Bandung, the head of the field in BPPD Bandung, taxpayers in 9 (nine) types of local taxpayers. The process of qualitative data analysis involves testing with triangulation, selection, categorization, evaluation, comparing, synthesizing, and contemplating the data that researchers get to construct inferences and then draw conclusions so as to achieve holistic understanding.

\section{RESUlts AND DiscuSSION}

The implementation of regional government in the era of regional autonomy should be followed by strong local financial support to implement and realize local government programs. The availability of financing in running the wheels of local government organizations is a must. The availability of local financial capacity needs to be improved by making efforts, one of which is to maximize PAD through local taxes.

Based on Law Number 28 the year 2009 regarding Regional Tax and Regional Retribution, it is stipulated that the authority of the Regency / City Government in the management of local taxes shall be divided into 11 (eleven) types of taxes, namely: (1) Hotel Tax; (2) Restaurant Tax; (3) Entertainment Tax; (4) Advertising Tax; (5) Street lighting tax; (6) Non-metallic and rock mineral taxes; (7) Parking Tax; (8) Ground Water Tax; (9) Swallow's Nest Tax; (10) Land Tax and Rural and Urban Buildings; and (11) Acquisition of Land and Building Rights.

To support the implementation of Law Number 28 The year 2009 the Local Government of Bandung City issued a Regional Regulation relating to local taxes. As for the implementation order of the Regional Regulation, the Government of Bandung City has issued the Regulation of Mayor as technical guidance in its implementation.

Potential sources of local tax revenues should be explored optimal, within the corridor of applicable legislation. For that Tariff of acquisition of right of land and building (BPPD), Bandung makes some strategies in its management. Strategies are statements that explain how goals and objectives will be achieved and then described in a series of policies.

Here's the direction of local tax management strategies undertaken BPPD Bandung.

\section{A. Completion of Local Tax Regulations}

Regulation of local taxation is a foothold which becomes the legal basis in levying local taxes. Bandung City Government to improve the local tax regulations by issuing some regulations. The regulations, among others:

1. Local Regulations. Regional Regulations related to the tariff of acquisition of right of land and building (BPHTB) have been issued; 2 the year 2011 on BPHTB. In the same year, there was also a regulation on regional taxes. 20 of 2011 which has been changed into Local Regulation no. 6 years 2016.

2. Mayor's Rules and Decisions

a. Mayor of Bandung Regulation No. 615 of 2013 on the Implementation of Online System on Data of 
Taxpayer Business Transactions in the Framework of Supervision of Local Tax Payments.

b. Mayor of Bandung Regulation No. 016 of 2014 on Standard Operating Procedures Procedure of Collection of Local Taxes.

c. The mayoral rules for each type of local tax have been issued, among others:

(1). Tax Hotel Tax Arrangement, namely Mayor Regulation No. 386 the year 2012 as amended by Mayor of Bandung Regulation No. 301 the year 2013 on Amendment of Mayor of Bandung Regulation No. 386 the year 2012 on Tax Collection Procedure Hotel. Then Bandung Mayor Regulation No. 1323 the year 2014 on the Second Amendment of the Mayor of Bandung Regulation No. 386 the year 2012 on Tax Collection Procedure Hotel.

(2). Procedures for Collection of Restaurant Tax, namely Mayor Regulation no. 387 the year 2012 as amended by Mayor of Bandung Regulation No. 302 the year 2013 on Amendment of Mayor of Bandung Regulation No. 387 the year 2012 on the Procedure of Collection of Restaurant Tax. Then Bandung Mayor Regulation No. 1324 the year 2014 on the Second Amendment of the Mayor of Bandung Regulation No. 387 the year 2012 on the Procedure of Collection of Restaurant Tax.

(3). Procedures for Collection of Entertainment Tax, namely Mayor Regulation no. 388 the year 2012 as amended by Mayor of Bandung Regulation No. 303 the year 2013 on Amendment to Mayor of Bandung Regulation No. 388 the year 2012 on Procedures for Collection of Entertainment Tax. Then Bandung Mayor Regulation No. 1325 the year 2014 on the Second Amendment to the Mayor of Bandung Regulation No. 388 the year 2012 on the Procedure of Tax Collection Entertainment.

(4). Procedures for Tax Collection Advertising, namely Mayor Regulation No. 389 the year 2012 as amended by Mayor of Bandung Regulation No. 304 the year 2013 on Amendment of Mayor of Bandung Regulation No. 389 the year 2012 on Procedures of Tax Collection Advertising. Then Bandung Mayor Regulation No. 1326 the year 2014 on the Second Amendment of Mayor Regulation Bandung No. 389 the year 2012 on the Procedure of Tax Collection Advertising.

(5). Procedures for Road Information Tax Collection, namely Mayor's Regulation No. 390 the year 2012 as amended by Mayor of Bandung Regulation No. 305 the year 2013 on Amendment of Mayor of Bandung Regulation No. 390 the year 2012 on the Procedure of Road Information Tax Collection. Then Bandung Mayor Regulation No. 1327 the year 2014 on the second
Amendment of Mayor Regulation Bandung No. 390 the year 2012 on the Procedure of Road Information Tax Collection.

(6). Parking Tax Collection Procedure, the Mayor's Regulation No. 391 the year 2012 as amended by Mayor of Bandung Regulation No. 306 the year 2013 on Amendment of Mayor of Bandung Regulation No. 391 the year 2012 on the Procedure of Parking Tax Collection. Then Bandung Mayor Regulation No. 1328 the year 2014 on the Second Amendment of Mayor Regulation Bandung No. 391 the year 2012 on the Procedure of Parking Tax Collection.

(7). Parking Tax Collection Procedure, the Mayor's Regulation No. 392 the year 2012 as amended by Mayor of Bandung Regulation No. 307 the year 2013 on Amendment to Mayor Bandung Regulation No. 392 the year 2012 on Procedures for Collection of Ground Water Tax. Then Bandung Mayor Regulation No. 1329 the year 2014 on the Second Amendment of Mayor Regulation Bandung No. 392 the year 2012 on Procedures for Collection of Ground Water Tax

(8). Procedures for tariff of acquisition of right on land and building, namely Mayor Regulation No. 393 the year 2012 as amended by Mayor of Bandung Regulation No. 308 the year 2013 on Amendment to Mayor of Bandung Regulation No. 393 the year 2012 on Procedure for Collection of Acquisition of Land and Building Rights. Then Bandung Mayor Regulation No. 1330 the year 2014 on the Second Amendment of Mayor Regulation Bandung No. 393 the year 2012 on the Procedure of Collection of Tax on Acquisition of Land and Building Rights.

(9). Land and Building Taxes, namely Mayor Regulation (PBB) No. 887 the year 2012 as amended by Mayor of Bandung Regulation No. 309 the year 2013 on Amendment to Mayor of Bandung Regulation No. 887 the year 2012 on Technical Guidelines and Procedures for Collection of Land and Building Tax. Then Bandung Mayor's Regulation No. 1331 the year 2014 on the Second Amendment of Bandung Mayor's Regulation No. 887 the year 2012 on Technical Guidelines and Procedures for Collection of Land and Building Tax. Then the Decree of Mayor of Bandung Number 973 / Kep.006-Disyanjak / 2014 on Stipulation of NJOP as the Base for the Implementation of the United Nations for Bandung Year 2014.

\section{B. Optimization of Local Tax Collection}

BPPD Bandung has done the steps of intensification of local tax revenue, as follows:

(1). Expanding the Acceptance Base. Actions taken to expand the revenue base that can be collected by the 
region, which in the economic calculation is considered potential, among others, that is identifying new/potential taxpayers and the number of taxpayers, improve the object database, improve the assessment, calculate the capacity of acceptance of each type of levy with analysis or potential tax data.

(2). Strengthening the Collection Process. Efforts made in strengthening the collection process, among others, accelerate the preparation of local tax regulations in the form of local regulations/regulation of the mayor, changing tariffs, especially local tax rates and increasing human resources.

(3). Improving Supervision. This can be enhanced, among other things, by conducting periodic and periodic checks, improving the monitoring process, applying sanctions to taxpayers and sanctions against the tax authorities, and increasing the payment of taxes and services provided by the regions.

(4). Improve Administrative Efficiency and Suppress Collecting Charges. Measures undertaken by the region are among others improving tax administration procedures through simplification of tax administration, increasing the efficiency of collection of each type of collection.

(5). Increasing Local Tax Revenue Capacity Through Better Planning. This can be done by improving coordination with relevant agencies in the regions.

The intensification efforts above have resulted in the inclusion of new taxpayers throughout 2015 as many as 15,986 , which consists of:

Table 3. Local Tax Realization Bandung

\begin{tabular}{|c|c|c|c|c|c|c|}
\hline No & Types of Tax & 2012 & 2013 & 2014 & 2015 & 2016 \\
\hline 1 & Hotel Tax & 142.732 .317 .105 & 177.490 .303 .830 & 204.149 .137 .826 & 215.285 .361 .236 & 274.707 .724 .831 \\
\hline 2 & Restaurant Tax & 97.356 .787 .188 & 118.700 .322 .856 & 142.376 .159 .558 & 181.868 .358 .705 & 241.567 .206 .844 \\
\hline 3 & Entertainment Tax & 34.553 .186 .144 & 37.767 .188 .531 & 40.730 .151 .211 & 50.449 .101 .884 & 69.817 .108 .446 \\
\hline 4 & Tax of Road Information & 118.646 .202 .927 & 135.297 .036 .036 & 159.123 .681 .023 & 178.144 .137 .262 & 177.358 .328 .595 \\
\hline 5 & Tax Parking & 7.135 .692 .799 & 7.796 .908 .376 & 12.150 .329 .775 & 20.234 .816 .571 & 28.699 .948 .562 \\
\hline 6 & BPHTB & 398.574 .514 .052 & 415.761 .410 .854 & 418.787 .336 .368 & 399.885 .860 .295 & 440.329 .214 .279 \\
\hline 7 & Advertisement Tax & 18.575 .238 .358 & 17.603 .910 .300 & 23.641 .404 .085 & 18.107 .052 .336 & 25.646 .023 .584 \\
\hline 8 & Groundwater Tax & 3.471 .181 .769 & 3.566 .097 .210 & 26.017 .976 .057 & 30.260 .440 .425 & 33.489 .085 .624 \\
\hline 9 & PBB & & & 372.206 .543 .770 & 391.020 .956 .093 & 417.134 .044 .862 \\
\hline
\end{tabular}

\section{Determination of Target Plan of Local Tax Revenue}

The Government of Bandung always trying to explore all the potential of local taxes that can be a source of local revenue. Determination of the target size of local tax revenue is done in specific, measurable and justified well. Determination of tax target plan prepared by Planning Section BPPD Bandung in cooperation with universities. The
Table 2. New Taxpayers

\begin{tabular}{|l|r|r|}
\hline \multicolumn{1}{|c|}{ Tax Objects } & $\begin{array}{c}\text { Number } \\
\text { Confirmed }\end{array}$ & $\begin{array}{c}\text { Total Tax Revenues } \\
\text { Taxpayer Realization }\end{array}$ \\
\hline Hotel Tax & 295 & 13.857 .509 .950 \\
\hline Restaurant Tax & 735 & 13.735 .524 .784 \\
\hline Hotel Tax & 56 & 2.031 .004 .769 \\
\hline Tax Parking & 67 & 2.888 .998 .945 \\
\hline PBB & 12.084 & 7.015 .829 .702 \\
\hline Advertisement Tax & 2.469 & 7.485 .705 .727 \\
\hline Groundwater Tax & 280 & 540.957 .446 \\
\hline Total New Taxpayers & $\mathbf{1 5 . 9 8 6}$ & $\mathbf{4 7 . 5 5 5 . 5 3 1 . 3 2 3}$ \\
\hline
\end{tabular}

The addition of new taxpayers registered in 2015 consists of 7 taxes, with the highest addition achieved by the PBB as many as 12,084 new taxpayers. The addition of PBB taxpayers is due to the updating of the PBB database for the five areas of the tax service unit which allows the availability of more accurate data from each tax object of the PBB.

The addition of new taxpayers certainly contributes to the increase in tax revenue in 2015. This is evidenced by the amount of tax revenue generated specifically from the new taxpayers reached 47.5 billion. It can be seen from Table 2 above that for new taxpayers, the highest revenue increase is generated from hotel taxpayers contributing 13.8 billion. While the PBB despite the addition of the highest taxpayers but does not guarantee to contribute large enough to local tax revenue.

The existence of tax revenue intensification program conducted by BPPD Bandung proved tax revenue during the last 5 (five) years has always increased. Here is the development of local tax revenue Bandung.

Table 3. Target Regional Tax Bandung

\begin{tabular}{|c|c|c|c|c|c|c|}
\hline No & Types of Tax & 2012 & 2013 & 2014 & 2015 & 2016 \\
\hline 1 & Hotel Tax & 99.000 .000 .000 & 145.000 .000 .000 & 199.350 .000 .000 & 260.000 .000 .000 & 260.000 .000 .000 \\
\hline 2 & Restaurant Tax & 78.000 .000 .000 & 99.000 .000 .000 & 135.000 .000 .000 & 170.000 .000 .000 & 235.000 .000 .000 \\
\hline 3 & Entertainment Tax & 30.000 .000 .000 & 35.000 .000 .000 & 45.000 .000 .000 & 60.000 .000 .000 & 68.000 .000 .000 \\
\hline 4 & Tax of Road Information & 102.000 .000 .000 & 120.000 .000 .000 & 156.000 .000 .000 & 180.000 .000 .000 & 173.200 .000 .000 \\
\hline 5 & Tax Parking & 6.500 .000 .000 & 7.500 .000 .000 & 12.000 .000 .000 & 30.000 .000 .000 & 26.000 .000 .000 \\
\hline 6 & BPHTB & 240.000 .000 .000 & 350.000 .000 .000 & 439.650 .000 .000 & 428.150 .000 .000 & 660.000 .000 .000 \\
\hline 7 & Advertisement Tax & 13.200 .000 .000 & 18.500 .000 .000 & 23.000 .000 .000 & 15.000 .000 .000 & 316.716 .770 .000 \\
\hline 8 & Groundwater Tax & 2.500 .000 .000 & 6.000 .000 .000 & 30.000 .000 .000 & 32.850 .000 .000 & 32.500 .000 .000 \\
\hline 9 & PBB & & & 360.000 .000 .000 & 422.000 .000 .000 & 415.000 .000 .000 \\
\hline \multicolumn{2}{|c|}{ Jumlah } & 571.200 .000 .000 & 781.000 .000 .000 & 1.400 .000 .000 .000 & 1.598 .000 .000 .000 & 2.186 .416 .770 .000 \\
\hline
\end{tabular}


The existence of the tax target will help the tax authorities perform their duties and functions optimally in accordance with the universal principles of tax collection. Thus, it is natural that almost all tax authorities are very concerned to know how much the target of tax revenues imposed on them.

\section{Develop Tax Incentives / Disincentives Policy}

Tax incentives are a form of tax facility provided by the government to certain taxpayers in the form of tax rate reduction that aims to reduce the amount of tax burden that must be paid. The tax incentive policy will actually reduce local tax revenues. However, this policy can accommodate the fulfillment of aspects of justice and the ability of the community in the imposition of local taxes.

Local tax incentive policy in Bandung is based on Bandung Mayor's Regulation No. 1331 the year 2014 on the third amendment to Mayor Regulation No. 887 the year 2012 on Technical Guidelines and Procedures for Collection of Land and Building Tax in article 27 paragraph 4 letter a, b, and $\mathrm{c}$ regarding granting tax incentives/reductions or $\mathrm{PBB}$ exemptions.

\section{E. Building Tax Service System}

To facilitate the community and taxpayers in paying taxes, the Government of Bandung has made several breakthroughs. The breakthroughs, among others: (1) Build and develop an online tax management information system online; (2) Integrate the online tax information management system online; (3) Integrate the location of BPPD offices and provide adequate and representative Tax Service Unit buildings; (4) Improve monitoring and evaluation of ITbased tax revenue realization; and (5) Conduct socialization of tax laws and regulations

\section{F. Increasing Public Awareness and Taxpayers}

Public awareness or compliance in paying taxes is a comparison between taxpayers who pay taxes to total taxpayers. The greater the percentage of taxpayers who pay taxes means that the level of public awareness or compliance in paying higher taxes. While the timeliness of taxpayers in paying taxes is the comparison of the number of Taxpayers who pay on time with the total taxpayers who pay taxes.

The level of tax compliance is a calculation of 7 (seven) taxes, where BPHTB and General Street Illumination Tax (PPJ) are not included in the taxpayer's compliance calculation because the method of payment of BPHTB and PPJ is not determined by the due date. There are several programs that are run to raise awareness and timeliness in paying taxes, among others: (1) Orderly Counseling of Regional Tax Administration; (2) Conduct a Taxpayer gathering; and (3) To enforce the law in order to increase taxpayer compliance

\section{G. Building a Tax Supervision System}

Bandung Local Regulation No. 20 of 2011 on Regional Tax which has been amended into Local Regulation No. 06 the year 2016. in it regulate about 9 types of taxes that are managed include:
(1). Tax Registration, consisting of: Hotel Tax, Restaurant Tax, Entertainment Tax, Street Lighting Tax, Parking Tax, and BPHTB.

(2). Tax Stipulation, consisting of Advertisement Tax, Ground Water Tax, and PBB.

Tax registration in accordance with the opinion of Mardisamo (2009) belongs to the tax group Self Assessment System, which is a tax collection system that authorizes taxpayers to determine for themselves the amount of tax payable .. While the determination tax included in the tax group Official Assessment System is a tax collection system that authorizes the government (tax authorities) to determine the amount of tax payable by the taxpayer. In this system, the Tax Service City of Bandung applies to the tax type which views the taxpayer enough to be responsible for calculating and assigning its own tax debt namely Hotel Tax, Restaurant Tax, Entertainment Tax and (BPHTB. In the Self Assessment system; tax administration plays an active role in conducting guidance, supervision, and implementation of sanctions on the delay of a fulfillment of tax obligations. The supervisory function holds

During this implementation of the supervision of local taxes, especially the type of registration tax carried out manually. However, since the year 2015 conducted installation of Tapping Box on taxpayers as a comparison tool with the Daily Sales Report should be reported by the taxpayer as a basis for imposition of local tax.

\section{Conclusion}

Local taxes that are entitled to be managed by the city/district government are based on Law no. 28 The year 2009 is about Local Tax and Levy Area. There are 11 types of local taxes in the law that are entitled to be collected by the city/county government. However, the collection of local taxes in Bandung City is based on Local Regulation No. 20 of 2011ada 9 types of local taxes, among others: (1) Hotel Taxes; (2) Restaurant Tax; (3) Entertainment Tax; (4) Advertising Tax; (5) Street lighting tax; (6) Parking Tax; (7) Ground Water Tax; (9) Land and Building Tax; and (11) BPHTB.

In general, the efforts undertaken by the Government of Bandung in order to increase local tax revenues through optimizing the intensification of local tax collection, among other things done in ways, among others: (1) Improvement of local tax regulations; (2) Optimization of local tax collection; (3) Determination of target plan of regional tax revenue; (4) Establish a tax incentive / disincentive policy; (5) Building a Pahaj Service System; (6) Increasing public awareness and taxpayers; and (7) Establish a tax oversight system.

\section{ACKNOWLEDGMENT}

Directorate of Research and Community Service, Ministry of Research and Technology Higher Education Republic of Indonesia. 


\section{REFERENCES}

(1). Lutfi A, , "Penyempurnaan Administrasi Pajak Daerah dan Retribusi Daerah : Suatu upaya dalam optimalisasi penerimaan PAD”, Jurnal Ilmu Administrasi dan Organisasi : Bisnis \& Birokrasi, Volume XIV, Nomor 1, Januari 2006, Departemen Ilmu Administrasi, Fakultas Ilmu Sosial dan Ilmu Politik, Universitas Indonesia. 2006

(2). Kajian Potensi Pafak dan Retribusi Daerah Kota Bandung, Bandung: LPPM Unpad, 2015.

(3). Nugroho. Riant. Kebijakan Publik Formulasi, Implementasi dan Evaluasi. Elexmedia Komputindo, Jakarta, 2006.
(4). Siahaan, Marihot P, Pajak Daerah dan Retribusi Daerah, Jakarta : Raja Grafindo Persada, 2005

(5). Silvani, Carlos A., Tax Administration Reform and Fiscal Adjustment. International Monetary Fund, 2007.

(6). Suryanto dan Rasmin, Mas, Perpajakan di Indonesia, Bandung: Unpad Press, 2017.

(7). Undang-undang No.33 Tahun 2004 tentang Perimbangan Keuangan antara Pemerintah Pusat dan Daerah.

(8). Undang-Undang Nomor 28 tahun 2009 tentang Pajak Daerah dan Retribusi Daerah. 